\title{
In vivo digestion of infant formula in piglets: protein digestion kinetics and release of bioactive peptides
}

\author{
Karima Bouzerzour ${ }^{1,2,3}$, François Morgan ${ }^{3}$, Isabelle Cuinet ${ }^{3}$, Cécile Bonhomme $^{4}$, Julien Jardin ${ }^{1,2}$, \\ Isabelle Le Huërou-Luron ${ }^{5}$ and Didier Dupont ${ }^{1,2 *}$ \\ ${ }^{1}$ INRA, UMR 1253, STLO, Rennes, France \\ ${ }^{2}$ Agrocampus Ouest, UMR 1253, STLO, Rennes, France \\ ${ }^{3}$ Lactalis RED, Retiers, France \\ ${ }^{4}$ Lactalis Nutrition, Torcé, France \\ ${ }^{5}$ INRA, UR 1341, ADNC, St Gilles, France \\ (Submitted 12 September 2011 - Final revision received 4 January 2012 - Accepted 9 January 2012 - First published online 1 March 2012)
}

\section{Abstract}

The first months of life correspond to a key period in human life where dramatic physiological changes (establishment of microbiota, development of the immune system, etc.) occur. In order to better control these changes it is necessary to understand the behaviour of food in the gastrointestinal tract of the newborn. Infant formula is the only food for the newborn when breast-feeding is impossible. The kinetics of digestion of milk proteins and the nature of the peptides liberated in the small intestine throughout infant formula digestion have never been extensively investigated so far and were therefore studied using the piglet as a model of the newborn child. Piglets were fed infant formula by an automatic delivery system during $28 \mathrm{~d}$, and slaughtered 30, 90 and 210 min after the last meal. Contents of stomach, proximal and median jejunum and ileum were collected and characterised. The extent of $\beta$-lactoglobulin $(\beta$-lg), $\alpha$-lactalbumin $(\alpha-l a)$ and casein proteolysis was monitored by inhibition ELISA, SDS-PAGE, immunoblotting and MS. At 30 min after the last meal, caseins were shown to be extensively hydrolysed in the stomach. Nevertheless, peptides originating mainly from $\beta$-caseins (from 509 to $2510 \mathrm{Da}$ ) were identified in the jejunum and ileum of the piglets. $\beta$-Lg partially resisted gastric digestion but completely disappeared in the stomach after $210 \mathrm{~min}$. $\alpha$-La had a similar behaviour to that of $\beta$-lg. Two large peptides ( 4276 and $2674 \mathrm{Da}$ ) generated from $\beta$-lg were present in the ileum after 30 and $210 \mathrm{~min}$ and only one (2674 Da) after $90 \mathrm{~min}$.

\section{Key words: Digestion: Milk proteins: Piglets: Infant formula}

Protein digestion is a complex process resulting in the concerted action of digestive enzymes on dietary proteins and depending on many factors such as the type of dietary proteins, gastric and intestinal $\mathrm{pH}$, peptic activity, endogenous secretions, and motility.

Major differences in the composition of breast milk and infant formula (protein content, lipids, lactose, growth factors, immunoglobulins, enzymes, etc.) can make the way proteins are digested by the newborn different and can therefore modulate the physiology of the gut ${ }^{(1)}$. Although studies have been performed on different aspects of digestion (metabolism, gastric emptying, protein flow, etc.), there is very limited information in the literature on protein digestion in the infant.

During the neonatal period, the gastric hydrolysis of milk proteins by pepsin is limited due to the buffering capacity of milk that increases the $\mathrm{pH}$, thus limiting the activity of this acid protease ${ }^{(2)}$. Gastric emptying was shown to be faster with human milk than with casein-based formula- and cows' milk-fed children ${ }^{(3,4)}$. However, identical gastric emptying was found in preterm infants fed either a soluble milk protein (SMP)-predominant (caseins:SMP ratio 40:60) or a casein-predominant (caseins:SMP ratio 82:18) formula, the amount of all other nutrients and osmolality being similar ${ }^{(5)}$.

Several studies have been conducted in vitro on the digestion of milk proteins using various types of milk matrices including infant formula ${ }^{(6-8)}$. In human adults, it has been shown that intact protein can escape gastric digestion and reach the small intestine ${ }^{(9)}$. The major SMP, i.e. $\beta$-lactoglobulin $(\beta-\mathrm{lg})$, when ingested alone, was found completely intact in the jejunum of human adults whereas only $64 \%$ of $\beta-\lg$

Abbreviations: $\alpha$-la, $\alpha$-lactalbumin; LC, liquid chromatography; $\beta$-lg, $\beta$-lactoglobulin; SMP, soluble milk protein; Tris, 2 -amino-2-hydroxymethyl-propane1,3-diol.

*Corresponding author: Dr Didier Dupont, fax +33 223485350, email didier.dupont@rennes.inra.fr 
remained intact when adults were fed skimmed milk ${ }^{(10)}$ In contrast, caseins were extensively hydrolysed and no intact protein was found in the small intestine. In calves aged 1 month, $60 \%$ of $\beta$-lg remained intact in the stomach after $7 \mathrm{~h}$ raw skimmed milk ingestion ${ }^{(11)}$. Despite these numerous studies, an exhaustive characterisation of the extent of milk proteolysis in vivo in neonates has never been done for ethical reasons.

A myriad of bioactive peptides is contained in milk proteins and can be released during protein digestion. Numerous bioactivities, i.e. immunomodulating, antimicrobial, antioxidative, opiate, antihypertensive, osteoprotective and antilipaemic, have been described after in vitro and in vivo digestion of purified proteins, milk and dairy products. These bioactive peptides may exert their actions both locally on the intestinal barrier and the gut-associated lymphoid tissues and outside the gastrointestinal tract after passage in the blood, but in both cases need to survive the action of digestive enzymes. However, kinetics of appearance and nature of the peptides released in the gut after ingestion of a complex matrix-like infant formula have never been exhaustively studied in vivo.

The present study was performed to assess the hydrolysis of infant formula proteins in the different compartments (stomach, proximal jejunum, median jejunum and ileum) of the gut at different postprandial times using the piglet as a model for the human infant. This model has previously been shown to be relevant for studying different aspects (gastric emptying, evolution of stomach $\mathrm{pH}$, etc.) of protein digestion in human infants ${ }^{(12,13)}$. Residual proteins were quantified in different compartments of the gut at three times after the meal (30, 90 and $210 \mathrm{~min}$ ) by using an inhibition ELISA; peptides were identified by MS.

\section{Materials and methods}

\section{Diets}

A formula adapted to the energy and protein requirements of piglets was manufactured by Lactalis (Retiers). Compared with a standard infant formula, it contained higher amounts of proteins and lipids (and a lower amount of lactose) but the protein:lipid ratio was kept constant. Its chemical composition is given in Table 1 . The formula contained a mixture of skimmed milk powder and SMP in order to reach a caseins:SMP ratio of 40:60. The acronym SMP was used rather than whey proteins because the proteins used in the present

Table 1. Composition (\% DM) of infant formula adapted to piglets

\begin{tabular}{lc}
\hline & Composition \\
\hline Protein & $17 \cdot 7$ \\
Lipid & $43 \cdot 4$ \\
Carbohydrates & $32 \cdot 2$ \\
Minerals & $3 \cdot 7$ \\
Net energy $(\mathrm{kJ} / \mathrm{g})$ & $21 \cdot 1$ \\
\hline
\end{tabular}

study were obtained from the soluble phase of microfiltred and ultrafiltred milk and were native, whereas whey proteins are usually obtained after cheese manufacture and have been pasteurised. Lipids consisted of a mixture of vegetable oils. The formula was rehydrated at $20 \%$ in water (w/v) before distribution to piglets.

\section{Animals and feeding}

The experiment was conducted in compliance with the guidelines of the French Ministry of Agriculture for Use of Animals in Research (certificate of authorisation to experiment on living animals, no. 7676). Crossbred (Pietrain $\times$ (Large White $\times$ Landrace)) piglets from the experimental herd of INRA (Saint-Gilles, France) were used, regardless of sex. A total of eighteen piglets were separated from their mothers after $2 \mathrm{~d}$ and fed the formula with an automatic milk feeder as described previously ${ }^{(14)}$ for $26 \mathrm{~d}$. The experimental design was a complete block design with a $1 \times 3$ factorial arrangement of one diet and three slaughter times after the last meal (30, 90 and $210 \mathrm{~min}$ ). The daily net energy ration of $1450 \mathrm{~kJ} /$ body weight ${ }^{0.75}$ was partitioned into ten meals automatically distributed during the day. Body weights were recorded weekly, and feeding schedules were adjusted accordingly.

\section{Collection of digested samples}

At the age of $28 \mathrm{~d}$, piglets were allocated to three groups according to their slaughter times after the last meal: 30, 90 and $210 \mathrm{~min}$. They were slaughtered by electronarcosis immediately followed by exsanguination. Immediately after, the digestive tract was removed, dissected and digested samples were collected from four segments: stomach, proximal jejunum ( $2.5 \mathrm{~m}$ from the beginning of the small intestine), median jejunum (4-6m of the small intestine between the proximal jejunum and ileum) and ileum ( $1.5 \mathrm{~m}$ of the extremity of the small intestine).

The total content of each segment was collected, dispersed by Ultra-Turrax (IKA Ultra Turrax T18 basic; IKA® Werke $\mathrm{GmbH} \& \mathrm{Co}$.) for $1 \mathrm{~min}$ at $15600 \mathrm{rpm}$, and $\mathrm{pH}$ was measured. Sodium benzoate and phenylmethylsulfonyl fluoride (10 and $0.37 \mathrm{~g} / \mathrm{kg}$ content, respectively) were added to each digested sample in order to avoid further protein breakdown. All effluents were stored at $-20^{\circ} \mathrm{C}$ until further analyses.

\section{Chemical and biochemical analyses}

The digested samples collected from each piglet were analysed in duplicate for DM and total N. The DM of effluents was determined after drying samples in an oven at $105^{\circ} \mathrm{C}$ for $7 \mathrm{~h}$. Total $\mathrm{N}$ was determined in both formula and digested samples by the Dumas method ${ }^{(15)}$.

\section{Antibodies}

Mouse monoclonal antibodies specific for $\alpha$-lactalbumin $(\alpha-\mathrm{la})^{(16)}$ and $\beta-\lg ^{(17)}$ were obtained as previously described. Casein-specific monoclonal antibodies taken from INRA's collection were directed 
against the following fragments: $\beta$-casein (f133-150) (f39-19);

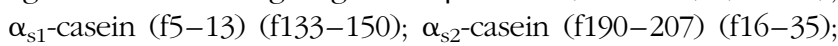
к-casein (98-115) (150-169). Rabbit polyclonal antibodies specific for proteins were of commercial origin, i.e. $\beta-\lg , \alpha$-la (Tebu-Bio) and total caseins (Gene Tex, Inc.).

\section{SDS-PAGE}

SDS-PAGE was performed using $10 \%$ polyacrylamide NuPAGE ${ }^{\circledR}$ Novex ${ }^{\circledR}$ Bis-Tris precast gels (Invitrogen) according to the manufacturer's instructions. All samples were centrifuged for $10 \mathrm{~min}$ at $12000 \mathrm{~g}$, defatted and supernatant fractions were diluted 4-fold with distilled water. Diluted samples $(32.5 \mu \mathrm{l})$ were treated with $5 \mu \mathrm{l}$ of $0.5 \mathrm{M}$-DL-dithiothreitol and $12.5 \mu \mathrm{l}$ of NuPAGE ${ }^{\circledR}$ LDS sample buffer before analysis.

Gels were fixed in $50 \%(\mathrm{v} / \mathrm{v})$ ethanol, $10 \%(\mathrm{v} / \mathrm{v})$ acetic acid and were rinsed for $15 \mathrm{~min}$ in deionised water before staining with Coomassie Blue. Molecular-weight markers used were the pure proteins $\beta$-casein, $\beta-\lg$ and $\alpha$-la. $\alpha$-La ${ }^{(18)}, \beta-\lg ^{(19)}$ and $\beta$-casein ${ }^{(20)}$ were purified as described previously. Image analysis of SDS-PAGE gels was carried out using Image Scanner II (Amersham Biosciences).

\section{Immunoblotting}

Digested samples and undigested infant formula were submitted to SDS-PAGE electrophoresis as described above. Immediately after separation, proteins and peptides were transferred onto a $0.2 \mu \mathrm{m}$ pore size polyvinylidene difluoride (PVDF) membrane (Bio-Rad) at $30 \mathrm{~V}$ and $250 \mathrm{~mA}$ for $90 \mathrm{~min}$ using a semi-dry transfer cell (Trans-Blot SD; Bio-Rad) using a $39 \mathrm{~mm}$-glycine, $48 \mathrm{~mm}$-2-amino-2-hydroxymethyl-propane1,3-diol (Tris), $0.0375 \%(\mathrm{w} / \mathrm{v})$ SDS and 20\% (v/v) methanol transfer buffer. Immunodetection was conducted according to the following procedure. The membrane was incubated at room temperature for $1 \mathrm{~h}$ periods in PBS with $0.3 \%$ (v/v) Tween-20 (PBS-T) with, successively, 5\% (w/v) decomplemented horse serum (Invitrogen), $\beta$-lg-, $\alpha$-la- or caseinsspecific mouse monoclonal antibodies $(1 \mathrm{ml}$ of each monoclonal antibodies at $0.5 \mu \mathrm{g} / \mathrm{ml}$ ) and goat anti-mouse $\mathrm{Ig}$ alkaline phosphatase conjugate at 1:500 (v/v). The membrane was washed between each step by soaking for $10 \mathrm{~min}$ in three changes of the same buffer (PBS-T). After the last washing, the membrane was stained with BCIP/NBT (5-bromo-4-chloro-3indolyl phosphate/nitro blue tetrazolium tablets) (Sigma) at $2.5 \mathrm{mg} / \mathrm{ml}$ in water. A negative control was made using a blot without monoclonal antibodies in order to detect non-specific bands.

\section{Inhibition ELISA}

Inhibition ELISA was performed as previously described ${ }^{(6)}$ using $\beta$-lg-, $\alpha$-la- and caseins-specific polyclonal antibodies to determine the residual immunoreactivity of each protein present in the four digestive compartments during the digestion process.

\section{Nano-liquid chromatography-MS/MS}

Jejunums (proximal and median jejunum pooled) and ileum contents of each piglet were analysed by liquid chromatography (LC)-MS/MS in order to identify the peptides remaining after digestion. After centrifugation for $10 \mathrm{~min}$ at $12000 \mathrm{~g}$, supernatant fractions were diluted in water $(1: 5, \mathrm{v} / \mathrm{v})$ and loaded onto a C18 cartridge (UPTI-CLEAN REC18; Interchim) and $200 \mu \mathrm{l}$ of $35 \%$ acetonitrile were added three times in order to recover peptides that were then dried in a Speed Vac Concentrator (SVC 100H; Savant Instruments Inc.) to eliminate all traces of acetonitrile. Dried samples were then diluted in $0.1 \%$ trifluoroacetic acid (Pierce), and $10 \mu \mathrm{l}$ were injected and trapped onto a micro-pre-column cartridge (C18 PepMap 100, $300 \mu \mathrm{m}$ internal diameter $\times 5 \mathrm{~mm}$; Dionex $)$ before separation of peptides onto a column (C18 PepMap $100,75 \mu \mathrm{m}$ internal diameter $\times 150 \mathrm{~mm}$; Dionex). The separation started with 5\% solvent B (95\% acetonitrile, 0.08\% formic acid and $0.01 \%$ trifluoroacetic acid in LC-grade water) and 95\% solvent A (2\% acetonitrile, 0.08\% formic acid and $0.01 \%$ trifluoroacetic acid in LC-grade water) for 5 min and a linear gradient from 5 to $70 \%$ of solvent $\mathrm{B}$ and from 95 to $30 \%$ of solvent A for 65 min was performed at a flow rate of $200 \mathrm{nl} / \mathrm{min}$.

The online separated peptides were analysed by electrospray ionisation quadrupole-time of flight MS in positive ion mode. An optimised voltage of $3 \cdot 2 \mathrm{kV}$ was applied to the nanoelectrospray ion source (Proxeon Biosystems A/S). MS and MS/MS data were acquired in continuum mode. Data-direct analysis was employed to perform MS/MS analysis on $1^{+}$to $4^{+}$charged precursor ions. Precursor selection was based upon ion intensity and charge state; if the precursors had been previously selected for fragmentation they were excluded from the rest of the analysis. Spectra were collected in the selected mass range of 400$2000 \mathrm{~m} / z$ for MS spectra and $60-2000 \mathrm{~m} / z$ for MS/MS. The mass spectrometer was operated in data-dependent mode automatically switching between MS and MS/MS acquisition using Analyst QS 1.1 software (Applied Biosystems) when the intensity of the ions was above 10 counts per s. To identify peptides, all data (MS and MS/MS) were submitted to MASCOT (v.2.2; Matrix Science). The search was performed against a homemade database dealing with major milk proteins which represents a proportion of the Swissprot database (http://www.expasy.org). No specific enzyme cleavage was used and the peptide mass tolerance was set to $0 \cdot 3 \mathrm{Da}$ for MS and MS/MS. For each peptide identified, a minimum MASCOT score corresponding to a $P$ value $<0.05$ was considered as a prerequisite for peptide validation

\section{Statistical analysis}

The data were analysed using the GLM procedure of SAS (version 8.1; SAS Institute, Inc.) using two separate ANOVA. Effect of time after the last meal and effect of proteins at each digestive site were tested. The values presented are least square mean values with their standard errors and effects were considered significant at $P \leq 0 \cdot 05$. Tendencies were reported when $0 \cdot 05 \leq P \leq 0 \cdot 10$. 


\section{Results}

All piglets were in good health throughout the experiment. Food intake and body-weight gain during the experimental period were similar in the three groups (30, 90 and $210 \mathrm{~min}$ after the last meal) of 28-d-old piglets. Formula intake during the last meal was 149 (SEM 14.4) g.

Table 2 shows the content, DM and $\mathrm{N}$ contents and residual immunoreactive proteins in the stomach, proximal jejunum, median jejunum and ileum at 30,90 and $210 \mathrm{~min}$ after the last meal. The drop in gastric $\mathrm{pH}$ with time was not significant (4.49, 4.46 and $3 \cdot 1$, respectively). The mean $\mathrm{pH}$ of small intestine contents was 5.7, 6.6 and $7 \cdot 2$ in the proximal and median jejunum and ileum, respectively, whatever the time after the last meal was. $\mathrm{N}$ significantly decreased with time in the stomach and proximal jejunum $(P=0.0034$ and $P=0.02$, respectively; Table 2). At time $30 \mathrm{~min}, 79$ (SEm 7.2) \% of ingested $\mathrm{N}$ was still present in the stomach of the piglet but only 39 (SEM 5.1) and 10 (SEM 3.2) \% were found in the stomach at 90 and $210 \mathrm{~min}$, respectively. In the proximal jejunum, ingested $\mathrm{N}$ was significantly higher at $30 \mathrm{~min}$ than at 90 and $210 \mathrm{~min}$ after the last meal (4.47 (SEM 0.44), 3.17 (SEM 0.55$)$ and 1.89 (SEM 0.33$) \%$, respectively).

\section{SDS-PAGE and immunoblotting}

SDS-PAGE gels showed different patterns between the three groups (Fig. 1). Only a few bands were detected in gastric contents after 210 min compared with those detected after 30 and $90 \mathrm{~min}$. SDS-PAGE showed an intense band corresponding to $\beta-\lg$ in the stomach at 30 and 90 min that totally disappeared $210 \mathrm{~min}$ after the last meal. Bands corresponding to $\alpha$-la also appeared in the stomach at 30 and $90 \mathrm{~min}$.

Western blotting with monoclonal antibodies that allow specific detection of $\beta-\lg , \alpha-\mathrm{la}$ and caseins were performed on the same effluents and on the undigested infant formula (Fig. 2(A), (B) and (C)). For $\beta$-lg, a major band at about $18 \mathrm{kDa}$ was revealed in the undigested infant formula and most, if not all, of the effluents analysed showed the presence of undigested $\beta-\lg$ in these samples (Fig. 2(A)). Bands at 25

Table 2. Content, DM and nitrogen content and residual immunoreactive proteins in the stomach, proximal jejunum, median jejunum and ileum at 30,90 and 210 min after the last meal

(Mean values with their standard errors)

\begin{tabular}{|c|c|c|c|c|c|c|c|}
\hline & \multicolumn{7}{|c|}{ Time after the last meal (min) } \\
\hline & \multicolumn{2}{|c|}{30} & \multicolumn{2}{|c|}{90} & \multicolumn{2}{|c|}{210} & \multirow[b]{2}{*}{ Time effect: $P$} \\
\hline & Mean & SEM & Mean & SEM & Mean & SEM & \\
\hline \multicolumn{8}{|l|}{ Stomach } \\
\hline Content (g) & $157 \cdot 00$ & $7 \cdot 19$ & $108 \cdot 27$ & $18 \cdot 52$ & 33.48 & $6 \cdot 80$ & 0.26 \\
\hline DM content $(\mathrm{g} / 100 \mathrm{~g})$ & $15 \cdot 00$ & 0.59 & $16 \cdot 13$ & 2.08 & 8.37 & $2 \cdot 36$ & 0.62 \\
\hline $\mathrm{N}$ content ( $\%$ of ingested $\mathrm{N})$ & $79 \cdot 00^{a}$ & $7 \cdot 2$ & $39 \cdot 24^{\mathrm{b}}$ & 5.08 & $10 \cdot 05^{c}$ & $3 \cdot 61$ & 0.0034 \\
\hline Content $\mathrm{pH}$ & 4.49 & 0.34 & 4.46 & 0.27 & $3 \cdot 10$ & 0.51 & 0.44 \\
\hline$\beta-\operatorname{Lg}(\%)$ & $45 \cdot 00^{a}$ & $12 \cdot 31$ & $16^{a, b}$ & 3.91 & $1.40^{\mathrm{b}}$ & 0.42 & 0.024 \\
\hline$\alpha$-La (\%) & $42.57^{a}$ & 8.44 & $16 \cdot 54^{\mathrm{b}}$ & $3 \cdot 19$ & $0.07^{c}$ & 0.03 & $<0.0001$ \\
\hline Caseins (\%) & $23 \cdot 76^{a}$ & 5.95 & $6 \cdot 16^{\mathrm{b}}$ & $2 \cdot 47$ & $0 \cdot 18^{b}$ & 0.05 & 0.003 \\
\hline \multicolumn{8}{|l|}{ Proximal jejunum } \\
\hline Content (g) & $10 \cdot 15$ & $1 \cdot 78$ & $7 \cdot 77$ & $1 \cdot 23$ & $8 \cdot 97$ & 1.94 & 0.97 \\
\hline DM content $(\mathrm{g} / 100 \mathrm{~g})$ & 12.98 & 1.09 & 12.96 & $2 \cdot 31$ & $3 \cdot 39$ & 0.72 & 0.90 \\
\hline $\mathrm{N}$ content ( $\%$ of ingested $\mathrm{N})$ & $4 \cdot 47^{a}$ & 0.44 & $3 \cdot 17^{\mathrm{b}}$ & 0.55 & $1 \cdot 89^{b}$ & 0.33 & 0.02 \\
\hline Content $\mathrm{pH}$ & 5.53 & 0.09 & 5.57 & 0.04 & $6 \cdot 03$ & 0.13 & 0.24 \\
\hline$\beta-\operatorname{Lg}(\%)$ & $1 \cdot 13$ & 0.31 & $2 \cdot 11$ & $1 \cdot 2$ & 0.05 & 0.02 & 0.27 \\
\hline$\alpha$-La (\%) & 0.64 & 0.37 & 0.77 & 0.66 & 0.01 & 0 & 0.48 \\
\hline Caseins (\%) & $0.27^{a}$ & 0.13 & $0.08^{a, b}$ & 0.02 & $0.01^{b}$ & 0 & $0 \cdot 10$ \\
\hline \multicolumn{8}{|l|}{ Median jejunum } \\
\hline Content (g) & 24.51 & $4 \cdot 14$ & $19 \cdot 24$ & $2 \cdot 73$ & $36 \cdot 31$ & $5 \cdot 77$ & 0.51 \\
\hline DM content $(\mathrm{g} / 100 \mathrm{~g})$ & $9 \cdot 83$ & 0.42 & $12 \cdot 59$ & $1 \cdot 32$ & $6 \cdot 63$ & 0.70 & 0.60 \\
\hline $\mathrm{N}$ content ( $\%$ of ingested $\mathrm{N})$ & $16 \cdot 59$ & $4 \cdot 28$ & $10 \cdot 99$ & $1 \cdot 14$ & $12 \cdot 97$ & $2 \cdot 08$ & 0.81 \\
\hline Content $\mathrm{pH}$ & $6 \cdot 91$ & 0.11 & $6 \cdot 47$ & 0.09 & $6 \cdot 28$ & 0.32 & 0.22 \\
\hline$\beta-\operatorname{Lg}(\%)$ & 0.18 & 0.06 & 0.18 & 0.05 & 0.13 & 0.04 & 0.79 \\
\hline$\alpha-\operatorname{La}(\%)$ & 0.21 & 0.09 & 0.17 & 0.04 & 0.14 & 0.03 & 0.64 \\
\hline Caseins (\%) & 0.18 & 0.05 & 0.16 & 0.03 & 0.1 & 0.04 & 0.84 \\
\hline \multicolumn{8}{|l|}{ Ileum } \\
\hline Content (g) & $12 \cdot 75$ & $5 \cdot 63$ & $7 \cdot 91$ & 1.08 & $9 \cdot 76$ & $3 \cdot 34$ & 0.36 \\
\hline DM content $(\mathrm{g} / 100 \mathrm{~g})$ & $11 \cdot 44$ & 1.09 & 14.95 & 0.69 & $11 \cdot 16$ & 1.91 & 0.52 \\
\hline $\mathrm{N}$ content ( $\%$ of ingested $\mathrm{N})$ & $8 \cdot 00$ & $1 \cdot 84$ & $6 \cdot 73$ & 0.82 & $6 \cdot 00$ & $2 \cdot 20$ & 0.89 \\
\hline Content pH & $7 \cdot 40$ & 0.03 & $7 \cdot 24$ & 0.05 & $7 \cdot 12$ & 0.24 & 0.27 \\
\hline$\beta-\operatorname{Lg}(\%)$ & 0.08 & 0.02 & 0.04 & 0.01 & 0.05 & 0.03 & 0.74 \\
\hline$\alpha-L a(\%)$ & 0.05 & 0.02 & 0.04 & 0.01 & 0.03 & 0.01 & 0.64 \\
\hline Caseins (\%) & 1.52 & 0.75 & 0.80 & 0.13 & 0.92 & 0.58 & 0.83 \\
\hline
\end{tabular}

$\beta$-Lg, $\beta$-lactoglobulin, $\alpha$-La, $\alpha$-lactalbumin.

${ }_{\mathrm{a}, \mathrm{b}, \mathrm{c}}$ Mean values within a row with unlike superscript letters were significantly different $(P<0.05)$. 


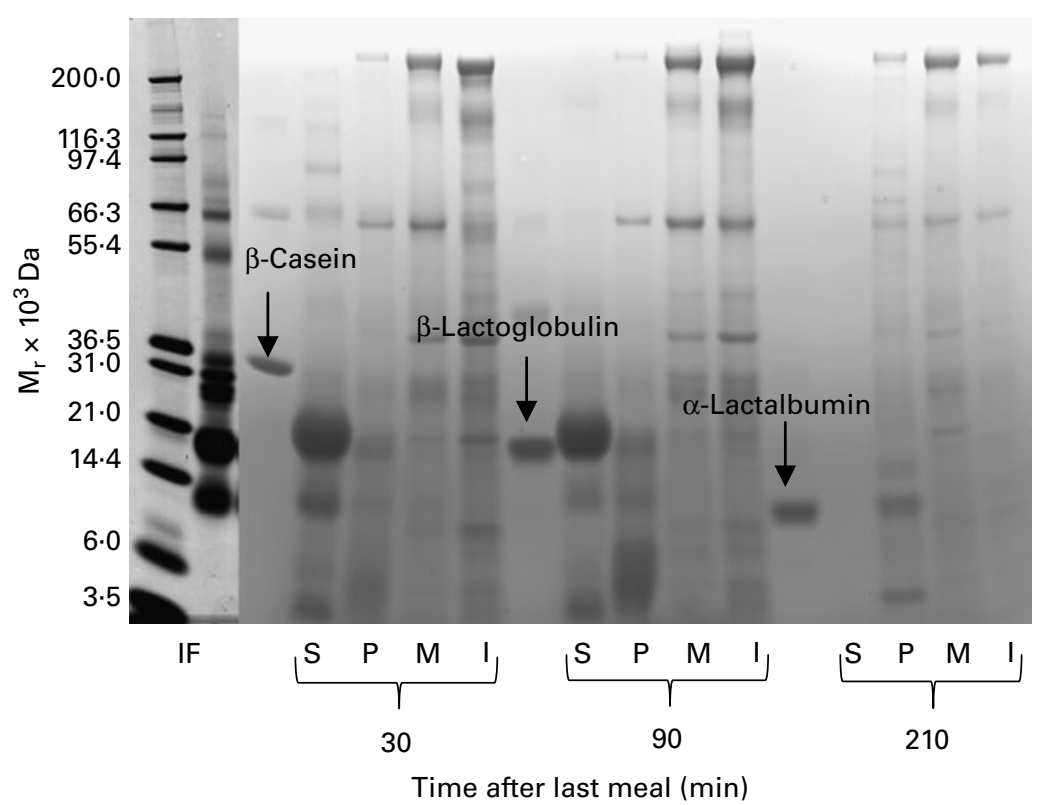

Fig. 1. SDS-PAGE analysis of undigested infant formula (IF) and contents of the stomach (S), proximal jejunum (P), median jejunum (M) and ileum (I) at 30,90 and $210 \mathrm{~min}$ after the last meal. $\mathrm{M}_{\mathrm{r}}$, molecular weight.

and $36 \mathrm{kDa}$ were detected in the undigested infant formula and also in the stomach and proximal jejunum effluents, the latter probably corresponding to dimers of $\beta$-lg. Most of the highmolecular-weight proteins revealed by immunoblot were the result of non-specific cross-reactions between the secondary antibody and the transferred proteins (Fig. 2(D)). For $\alpha$-la, a major band at about $14 \mathrm{kDa}$ was detected in the undigested infant formula and the stomach and proximal jejunum effluents (Fig. 2(B)). Dimers of $\alpha$-la were detected with the purified protein, the undigested infant formula and the stomach content collected $30 \mathrm{~min}$ after meal ingestion. Finally, caseins were revealed only in the purified protein control and undigested infant formula (Fig. 2(C)). Fragments of lower molecular weight (between 15 and $20 \mathrm{kDa}$ were visible in the median jejunum and ileum and might correspond to casein proteolysis products. These data clearly show that both $\beta$-lg and $\alpha$-la partly resist digestion and can be found as intact proteins in the effluents in contrast with caseins that are hydrolysed.

\section{Evolution of protein immunoreactivity during digestion}

A significant decrease in protein immunoreactivity with time was observed in the stomach (Fig. 3). At $30 \mathrm{~min}$ after the last meal, casein residual immunoreactivity was low in the stomach (23.7 (SEM 5.6)\%) and disappeared completely at $210 \mathrm{~min}$. In contrast, $\beta-\mathrm{lg}$ partially resisted gastric digestion after $30 \mathrm{~min}(45.6$ (SEM 12.3)\%) and completely disappeared at $210 \mathrm{~min}(1.37$ (SEM 0.42)\%). $\alpha$-La showed a similar behaviour to that of $\beta-\lg (42.6$ (SEM 8.4$) \%$ of $\alpha$-la remained immunoreactive in the stomach at $30 \mathrm{~min}$ ).

Surprisingly, $1 \%$ of casein residual immunoreactivity was still detected in the ileum at the three times after the last meal, whereas a low amount of immunoreactive $\beta$-lg and $\alpha$-la was detected in the ileum.
Identification of peptides in jejunums and ileum by liquid chromatography-MS/MS

Jejunum (proximal and median jejunum pooled) and ileum contents were subjected to LC-MS/MS to allow the identification of peptides with a minimum molecular mass of $400 \mathrm{Da}$. Only the peptides identified unambiguously $(P<0.05)$ as derived from $\beta$-lg, $\alpha$-la and caseins are shown in Fig. 4(A) and (B). Figure 4 . gives only the occurrence of peptides and their size distribution since the LC-MS/MS analysis, as it was performed in the present study, is rather qualitative than quantitative.

The mean number of peptides identified in the jejunum at each time was 13 (SEM 3), 12 (SEM 4) and 0.9 (SEm 0.3) peptides at 30, 90 and $210 \mathrm{~min}$, respectively (Fig. 4(A)). In the ileum, 1.3 (SEM 1.2), 1.0 (SEM 0.6) and 1.1 (SEM 0.9) peptides were detected at 30,90 and $210 \mathrm{~min}$ after the last meal, respectively (Fig. 4(B)).

Most of the peptides detected in the jejunum at the three times after the last meal were derived from $\beta$-casein. Their length varied between five and twenty-two amino acids (653 and $2510 \mathrm{Da})$ at $30 \mathrm{~min}$, four and eighteen amino acids $(552 \mathrm{Da}$ and $2085 \mathrm{Da}$ ) at $90 \mathrm{~min}$ and only four and six amino acids (509 and $788 \mathrm{Da}$ ) at $210 \mathrm{~min}$. In the ileum, only three peptides of $\beta$-casein were detected, with length ranging from five to eight amino acids (607 and $966 \mathrm{Da}$ ) at the three times. In contrast, $\alpha_{\mathrm{s} 1}$-casein generated only a very few peptides that were mainly identified in the jejunum at 30 and 90 min. Finally, only two peptides of $\kappa$-casein, i.e. $\kappa$-casein (f155-161) and $\kappa$-casein (f155-160), were detected in the jejunum at $30 \mathrm{~min}$ and two peptides from the same protein, i.e. $\mathrm{k}$-casein (f155-161) and $\mathrm{\kappa}$-casein (f115-121), in the jejunum at $90 \mathrm{~min}$.

Peptides of $\beta$-lg were detected in both jejunums and the ileum. Small peptides (seven to fifteen amino acids) of $\beta-\lg$ were detected in the jejunum at 30 and $90 \mathrm{~min}$ but none was 
(A)

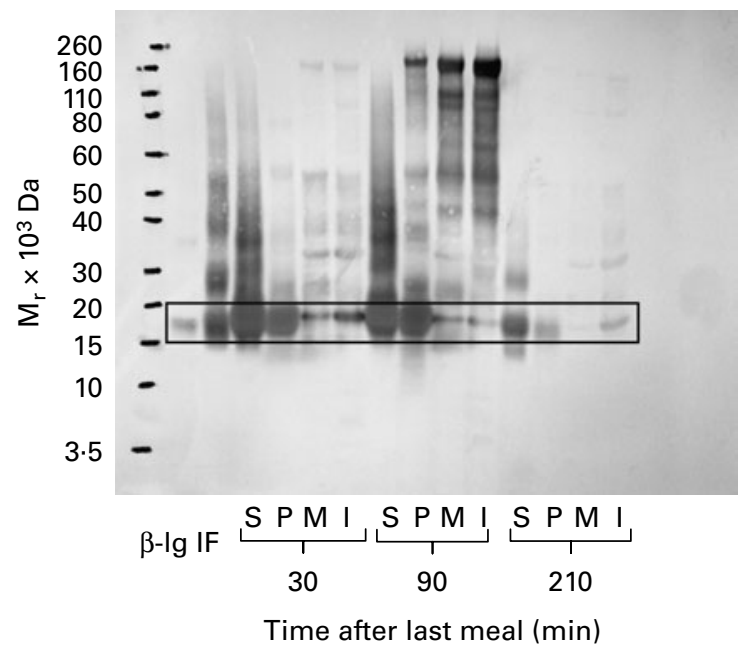

(C)

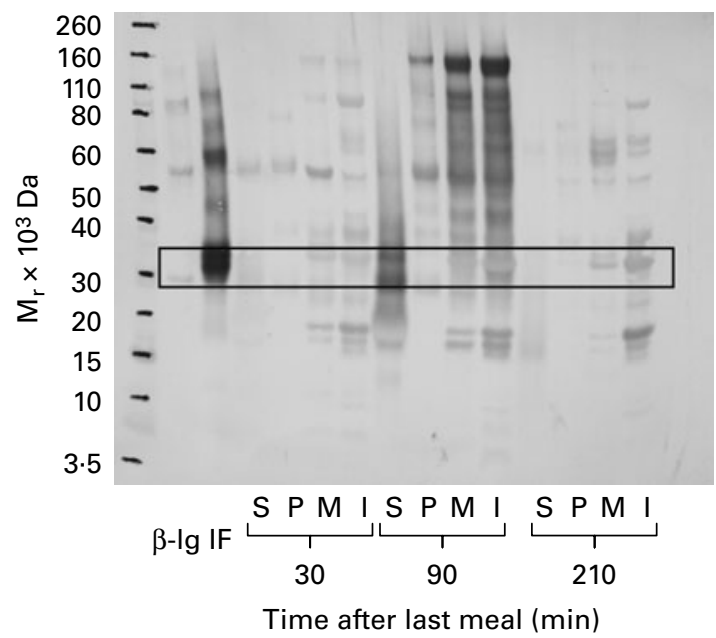

(B)

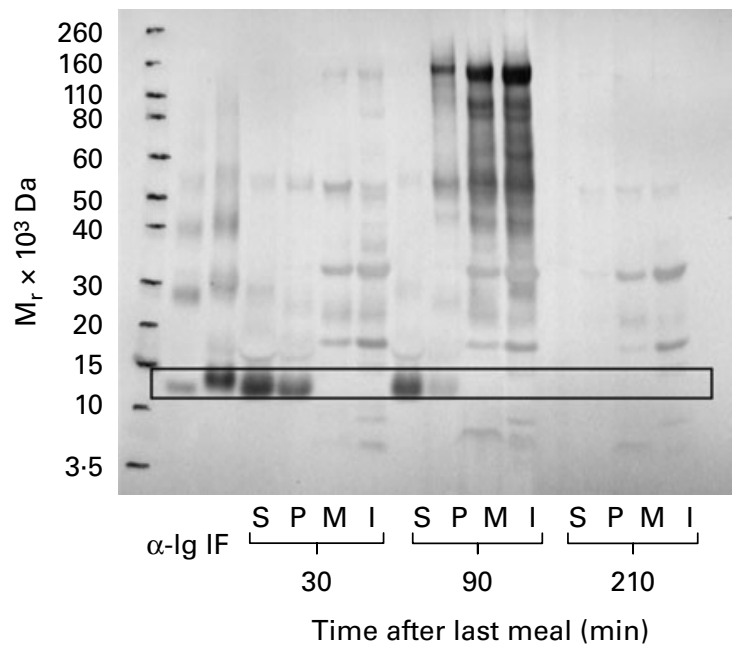

(D)

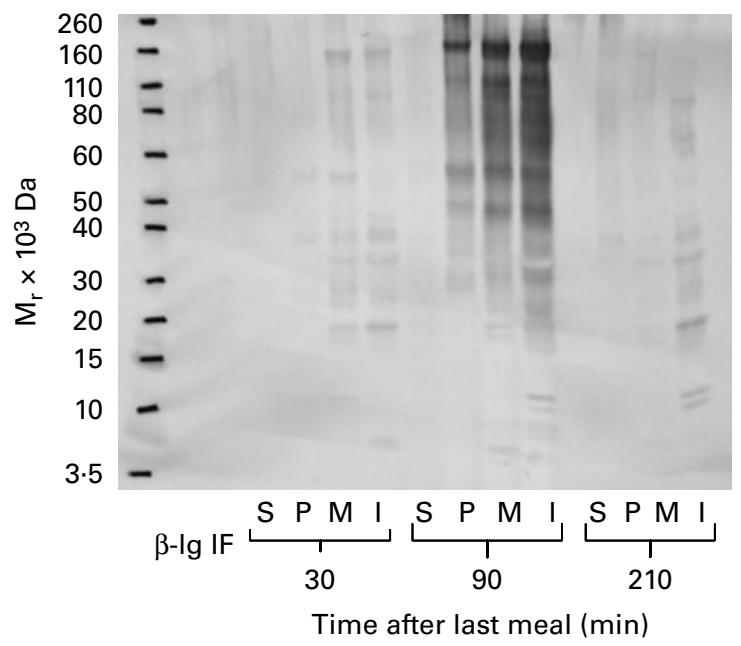

Fig. 2. Western blotting analysis of undigested infant formula (IF) and contents of the stomach (S), proximal jejunum (P), median jejunum (M) and ileum (I) at 30 , 90 and $210 \mathrm{~min}$ after the last meal using $\beta$-lactoglobulin $(\beta-\mathrm{lg})(\mathrm{A}), \alpha$-lactalbumin $(\alpha$-la) (B) and $\beta$-casein $(\beta-\mathrm{Cn})(\mathrm{C})$ monoclonal antibodies. (D) Negative control without monoclonal antibodies.

detected in the jejunum after $210 \mathrm{~min}$. Two large peptides (forty and twenty-three amino acids) of $\beta$ - $\lg$, i.e. $\beta-\lg$ (f1-40) and $\beta-\lg$ (f102-124), with molecular weights of 4276 and $2674 \mathrm{Da}$, respectively, were identified in the ileum at 30, 90 and $210 \mathrm{~min}$ for the smaller one, and 30 and $210 \mathrm{~min}$ for the biggest.

\section{Discussion}

The aim of the present study was to evaluate the kinetics of milk protein hydrolysis and peptide release in the gut using the piglet as a model of the human infant. The results obtained clearly show that caseins and SMP behave differently in the gastrointestinal tract of infant formula-fed piglets. $\beta$-Lg and $\alpha$-la appeared as the most resistant proteins towards digestion and were able to remain intact in the piglet stomach and proximal jejunum for more than $1 \mathrm{~h}$ after the meal ingestion. Although the hydrolysis of caseins in the upper gastrointestinal tract was very rapid, immunoreactive fragments and peptides were surprisingly detected in both the jejunum and ileum. Two large peptides of $\beta$-lg were also identified in the ileum. The rapid hydrolysis of caseins as compared with SMP has already been observed in vivo in 4-week-old rhesus monkeys ${ }^{(21)}$, human adults ${ }^{(10)}$, preruminant calves ${ }^{(11)}$ and also demonstrated in in vitro experiments ${ }^{(22-24)}$. We showed that about $45 \%$ of $\beta-\lg$ and $43 \%$ of $\alpha$-la remained detectable by ELISA in the stomach of piglets $30 \mathrm{~min}$ after the last meal while only $24 \%$ of caseins were detected. In human adults with a jejunostomy, Mahé et al. ${ }^{(10)}$ observed that $30 \mathrm{~min}$ after skimmed milk ingestion, 64 and $44 \%$ of $\beta-\lg$ and $\alpha$-la, respectively, remained intact, whereas caseins were entirely degraded. 
(A)

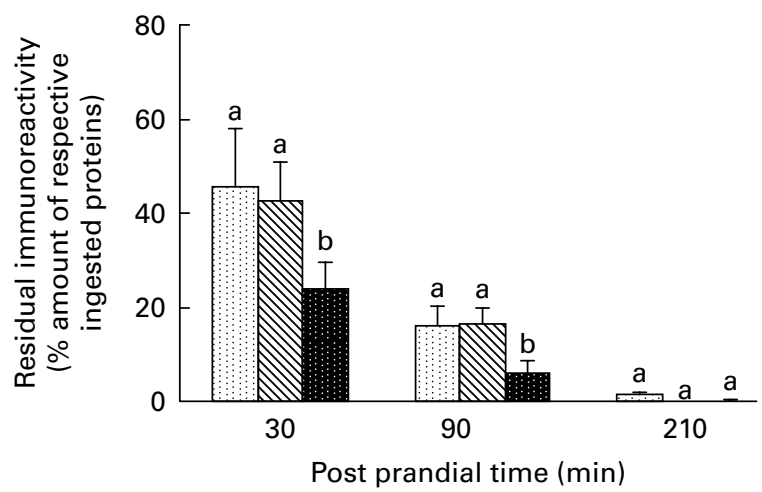

(C)

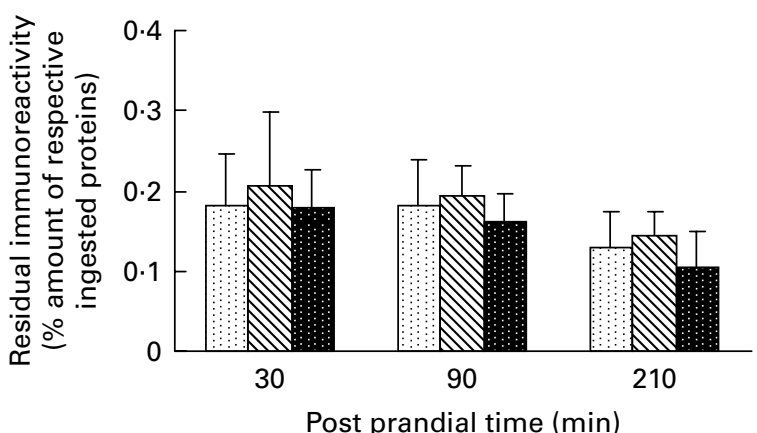

(B)

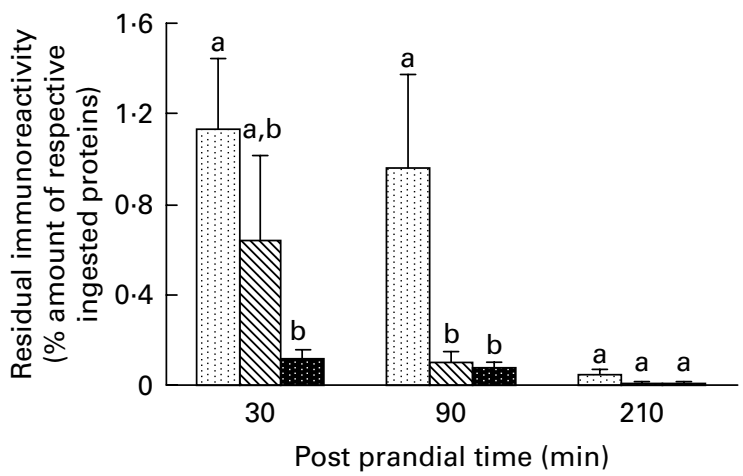

(D)

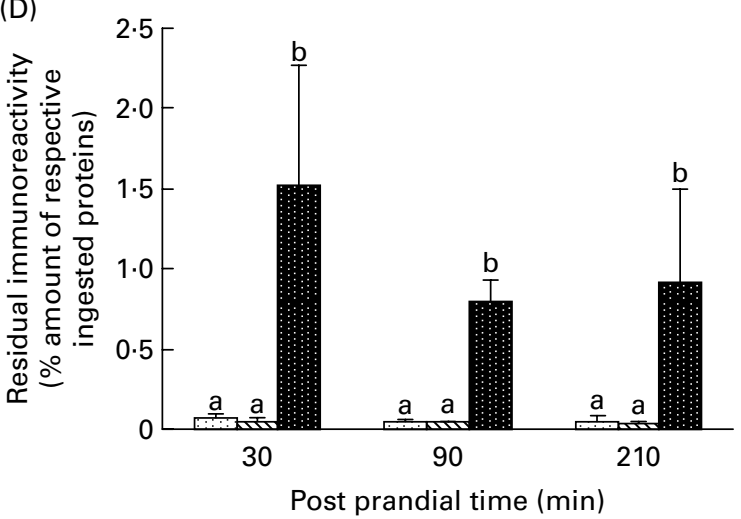

Fig. 3. $\beta$-Lactoglobulin (⿴), $\alpha$-lactalbumin $(\mathbb{\Xi})$ and casein $(\mathbf{B})$ residual immunoreactivity $(\%$ amount of respective ingested proteins) in the stomach $(A)$, proximal jejunum (B), median jejunum (C) and ileum (D) determined by inhibition ELISA. Values are means, with standard errors of the mean represented by vertical bars. ${ }^{\mathrm{a}, \mathrm{b}}$ Mean values at a postprandial time with unlike letters were significantly different $(P<0.05)$.

$\beta$-Lg has been shown to be resistant to digestion in many in vivo and in vitro studies but $\alpha$-la is a protein known to be prone to pepsin digestion in vitro. However, in the present study, $\beta-\lg$ and $\alpha$-la have the same patterns toward digestion. Moreno et $a l .{ }^{(25)}$ have found that the breakdown of $\alpha$-la during gastric digestion was slowed in the presence of phosphatidylcholine, with little effect being observed during subsequent duodenal digestion. At low $\mathrm{pH}, \alpha$-la has a partially unfolded form that allows it to penetrate into the phosphatidylcholine vesicles. These interactions are probably responsible for the slowing of gastric digestion by reducing the accessibility of the protein to pepsin. Mandalari et al. ${ }^{(26)}$ showed the same results with $\beta-\lg$.

$\mathrm{N}$ determination in the stomach showed that $30 \mathrm{~min}$ after ingestion, 79 (SEM $7 \cdot 2) \%$ of $\mathrm{N}$ was still present in the stomach of the piglet whereas 39 (SEM 5.1) and 10 (SEM 3.2)\% were found in the stomach after 90 and $210 \mathrm{~min}$, respectively. Only $24 \%$ of caseins and $45 \%$ of SPM were detected by ELISA $30 \mathrm{~min}$ after ingestion when $79 \%$ of the $\mathrm{N}$ (dietary + endogenous proteins) is still present in the stomach. The difference observed between the $79 \%$ residual $\mathrm{N}$ (dietary + endogenous) and the $45 \%$ residual SPM and $24 \%$ residual caseins can have different explanations: it can be either due to significant endogenous secretions or to an extensive hydrolysis and/or emptying of milk proteins making them not detectable by ELISA. The $\mathrm{pH}$ of stomach contents did not drop below 4 until 210 min after meal ingestion. The gastric $\mathrm{pH}$ levels are comparable with those reported by other workers for piglets at approximately the same age ${ }^{(27,28)}$ and for breast-fed neonates ${ }^{(2)}$. These relatively high $\mathrm{pH}$ can prevent casein coagulation and induce a fast gastric emptying of these proteins.

Despite the physiological differences between adults and infants (lower acid and enzyme secretions in infants), the present study demonstrated that the behaviour of milk proteins towards digestion is similar between infant and adult models, with differences in the extent of protein hydrolysis. This is in agreement with our recent in vitro data ${ }^{(22)}$. In vitro digestion of $\beta-\lg$ was similar between the infant and adult model during the gastric phase but in the duodenal phase 56 and $72 \%$ of $\beta-1 g$ remained intact in the infant and adult model, respectively. This higher resistance of $\beta$-lg towards digestion was attributed to an interaction between the protein and gastric phosphatidylcholine vesicles that were present at higher concentration in the adult. The high resistance of $\beta$-lg and $\alpha$-la to digestion can also be explained by the highly compact conformation assumed by $\beta$-lg and $\alpha$-la for the presence of two and four intramolecular disulfide bridges, respectively ${ }^{(29)}$.

The residual immunoreactivity of caseins, expressed as the percentage amount of ingested casein detected in the ileum at all the times tested, was higher than the residual activity of caseins in the proximal and median jejunum. It is hard to 
(A) $30 \mathrm{~min}$

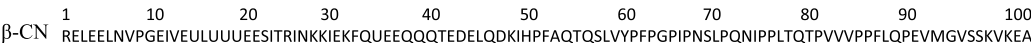

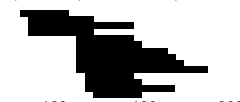

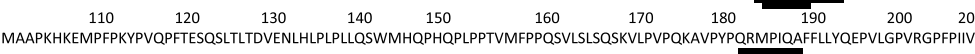

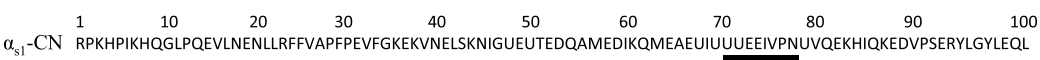

$\begin{array}{cccccccccc}110 & 120 & 130 & 140 & 150 & 160 & 170 & 180 & 190 & 199 \\ \text { LRLKKYKVPQLEIVPNUAERLHSMKEGIHAQQKEPMIGVNNELAYFYPELFRQFYQLDAYPSGAWYYPPLGQYTDAPSFSDIPNPIGSENSEKTTMPLW }\end{array}$

$\begin{array}{ccccccccc}1 & 10 & 20 & 30 & 40 & 50 & 60 & 70 & 80 \\ \beta-19 & \text { LIVTQTMKGLDIQKVAGTWYSLAMAASDISLDAQSAPLRVYVEELKPTPEGDEEILLKWENGECAQKKIIAEKTKI }\end{array}$

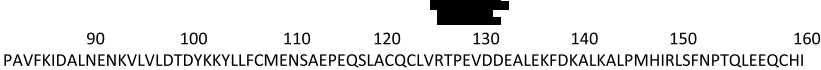

$90 \min$

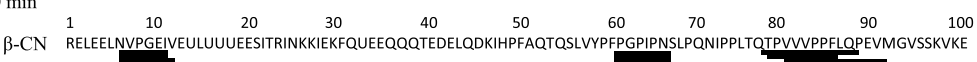

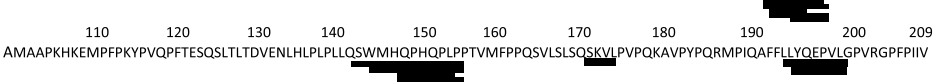

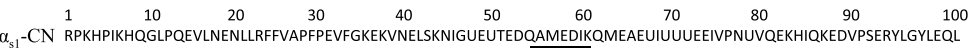

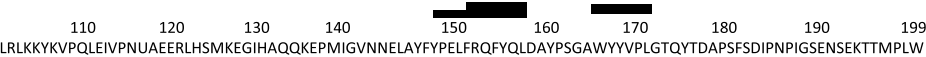

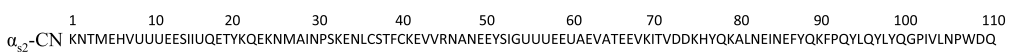

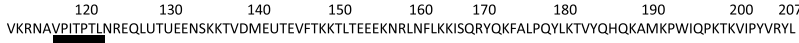

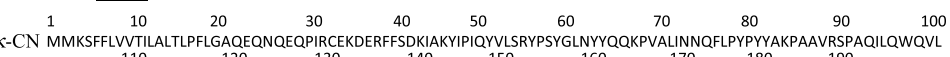

SNTVPAKSCOAQPTTMARHPHPHLLFMAIPPKKNQDKTEIPTINTIASGEPTSTPTTEAVESTVATLEDSPEVIESPPEINTVQVTSTAV

$\begin{array}{ccccccccc}1 & 10 & 20 & 30 & 40 & 50 & 60 & 70 & 80\end{array}$

$\begin{array}{lllllll}90 & 100 \quad 110 & 120 & -130 & 140 & 150 & 160\end{array}$

PAVFKIDALNENKVIVLDTOYKKYLFFCMENSAEPEQSLACQCLVRTPEVDDEALEKFDKALKALPMHIRISFNPTQLEEQCHI $210 \min$

$\begin{array}{rrrrrrrrrr}1 & 10 & 20 & 30 & 40 & 50 & 60 & 70 & 80 & 90\end{array}$

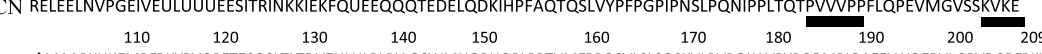

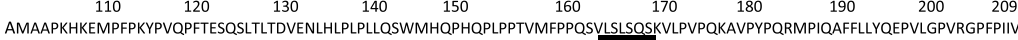

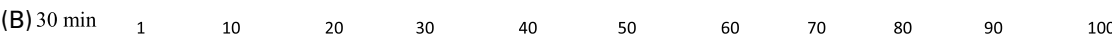

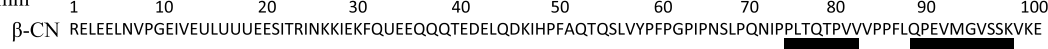
$\begin{array}{lllllllllll}110 & 120 & 130 & 140 & 150 & 160 & 170 & 180 & 190 & 200 & 209\end{array}$ $\begin{array}{lllllllll}1 & 10 & 20 & 30 & 40 & 50 & 60 & 70 & 80\end{array}$

$\beta$-lg LIVTQTMKGLDIQKVAGTWYSLAMAASDISLLDAQSAPLRVYVEELKPTPEGDLEILLKWENGECAQKKIIAEKTKIPA

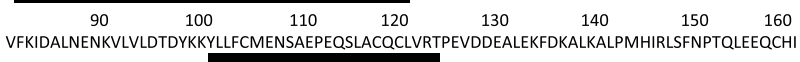

$90 \mathrm{~min}$

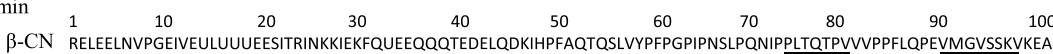
$110 \quad 120 \quad 130 \quad 140.150170180$

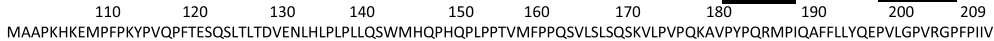

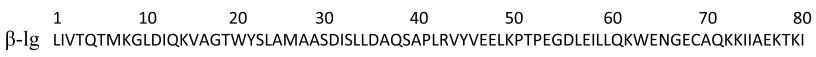

$\begin{array}{llllllll}90 & 100 & 110 & 120 & 130 & 140 & 150 & 160\end{array}$

$210 \min$

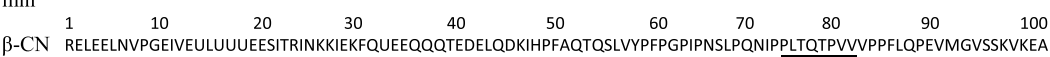

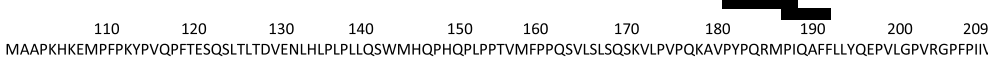

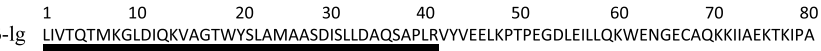

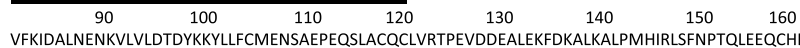

Fig. 4. Peptide identification in the jejunum (A) and ileum (B) of piglets at 30,90 and 210 min after the last meal using liquid chromatography-MS/MS. Cn, casein; Ig, lactoglobulin. 
conclude whether the $1.52 \%$ of immunoreactive caseins detected in the ileum 30 min after meal ingestion come from the test meal or a previous one. Our current hypothesis is that caseins have domains that are resistant to proteolysis in the gut ${ }^{(6)}$ and that these undigested fragments might be stored in the ileum due to the ileocaecal valve which slows undigested materials before passing into the large intestine. Similarly, about $1 \%$ immunoreactive fragments derived from caseins was found in the ileum of piglets at 90 and $210 \mathrm{~min}$. Are these fragments identical to the ones already described as being resistant to digestion? The intact fragments of caseins detected in the jejunum and ileum were mainly peptides from $\beta$-casein that were detected by LC-MS/MS in both the jejunum and ileum at 30,90 and $210 \mathrm{~min}$. We observed many peptides from the area $74-91$ of $\beta$-casein. This fits perfectly with the casein domains resisting proteolysis during digestion that have been identified in vitro using an infant digestion model as being the most resistant area of $\beta$-casein in raw, pasteurised and sterilised milks and yogurt ${ }^{(6)}$. Picariello et al. ${ }^{(29)}$ found that the C-terminal region of $\beta$-casein gave rise to very intense peptide signals after in vitro digestion of caseins. However, in the present study only few peptides from the C-terminal region of $\beta$-casein were detected in the jejunum 90 min after the meal. $\beta$-Lg peptides of seven to fifteen amino acids were detected in the jejunum at 30 and $90 \mathrm{~min}$ and large peptides of $\beta$-lg of twenty-three and forty amino acids were observed in the ileum. These peptides persist in the ileum until 210 min after the meal.

Some of the $\beta$-casein peptides detected in the present study are known to promote bioactivities, such as peptide $\beta$-casein (f60-66) and peptide $\beta$-casein (f80-90) that carry immunomodulatory activity in vitro and anti-hypertensive activity in spontaneously hypertensive rats, respectively ${ }^{(30-32)}$. Other peptides detected in both the jejunum and ileum can exert bioactivities. Peptides from $\beta-\lg$ and $\alpha$-la released by the action of digestive enzymes were shown to have the potential to influence the specific immune response through the modulation of murine splenocyte proliferation and cytokine secretion $^{(33,34)}$.

Peptide identification by MS is hard to achieve in complex samples such as intestinal contents. The present study is, to our knowledge, the first exhaustive characterisation of dietary peptides released during in vivo milk protein digestion.

In conclusion, the present study has established that $\beta-\mathrm{lg}$ and $\alpha$-la were more resistant than caseins to digestion in the stomach of piglets receiving infant formula 30, 90 and $210 \mathrm{~min}$ after the last meal. However, peptides derived mainly from $\beta$-caseins were present in the jejunum and ileum of piglets and can promote bioactivity. Caseins appear to be rapidly hydrolysed into large peptides in the stomach, since only $24 \%$ were detected $30 \mathrm{~min}$ after meal ingestion. However, it appears that this hydrolysis is incomplete and leads to the survival of domains that were detected in the ileum.

This finding provides support for studying the possibility that peptides found in the intestinal lumen modify intestinal functions and exert bioactivities.

\section{Acknowledgements}

The present study was presented at the 8th day of the French nutrition conference, 7-10 December 2010, Lille, France. The authors thank F. Kest for diet manufacturing, all of the staff involved in the animal care and feeding and in animal slaughtering, as well as G. Savary for the maintenance of incubators and automatic formula feeders. We also acknowledge O. Menard, Y. Le Gouar and M. Formal for their expert technical assistance. The authors are involved in the FA1005 COST Action INFOGEST on food digestion. The authors are solely responsible for the work described in this article. D. D. F. M. and I. L. were responsible for the project development. K. B. and I. L. conducted the experiments in piglets. K. B. D. D. and I. L. were responsible for analysis. K. B. and J. J. were responsible for LC-MS/MS analysis. I. C. was responsible for diet formulation. K. B. and I. L. were responsible for generating statistical analysis. K. B., I. L., C. B., J. J. and D. D. were responsible for drafting the manuscript.

There are no conflicts of interest.

\section{References}

1. Le Huërou-Luron I, Blat S \& Boudry G (2010) Breast- $v$. formula-feeding: impacts on the digestive tract and immediate and long-term health effects. Nutr Res Rev 23, 23-36.

2. Mason S (1962) Some aspects of gastric function in newborn. Arch Dis Child 37, 387-391.

3. Driessche M, Peeters K, Marien P, et al. (1999) Gastric emptying in formula-fed and breast-fed infants measured with the ${ }^{13} \mathrm{C}$-octanoic acid breath test. J Pediatr Gastroenterol Nutr 29, 46-51.

4. Billeaud C, Guillet J \& Sandler B (1990) Gastric emptying in infants with or without gastroesophageal reflux according to the type of milk. Eur J Clin Nutr 44, 577-583.

5. Thorkelsson T, Mimouni F, Namgung R, et al. (1994) Similar gastric emptying rates for casein-predominant and wheypredominant formulas in preterm infants. Pediatr Res $\mathbf{3 6}$, 329-333

6. Dupont D, Mandalari G, Molle D, et al. (2010) Food processing increases casein resistance to simulated infant digestion. Mol Nutr Food Res 54, 1677-1689.

7. Chatterton DEW, Rasmussen JT, Heegaard CW, et al. (2004) In vitro digestion of novel milk protein ingredients for use in infant formulas: research on biological functions. Trends Food Sci Technol 15, 373-383.

8. Sakai K, Yoshino K, Satter MA, et al. (2000) Effects of pH variation and $\mathrm{NaCl}$ on in vitro digestibility of cow's milk proteins in commercially available infant formulas. J Nutr Sci Vitaminol 46, 325-328.

9. Mahé S, Roos N, Benamouzig R, et al. (1996) Gastrojejunal kinetics and the digestion of $\left[{ }^{15} \mathrm{~N}\right] \beta$-lactoglobulin and casein in humans: the influence of the nature and quantity of the protein. Am J Clin Nutr 63, 546-552.

10. Mahé S, Messing B, Thuillier F, et al. (1991) Digestion of bovine milk proteins in patients with a high jejunostomy. Am J Clin Nutr 54, 534-538.

11. Scanff P, Yvon M, Pelissier JP, et al. (1992) Effect of some technological treatments of milk on in vivo gastric emptying of immunoreactive whey proteins. Lait 72, 43-51.

12. Darragh AJ \& Moughan PJ (1995) The three-week-old piglet as a model animal for studying protein digestion in human infants. J Pediatr Gastroenterol Nutr 21, 387-393. 
13. Moughan PJ, Birtles MJ, Cranwell PD, et al. (1992) The piglet as a model animal for studying aspects of digestion and absorption in milk fed human infants. World Rev Nutr Diet 67, 40-113.

14. Morise A, Sève B, Macé K, et al. (2009) Impact of intrauterine growth retardation and early protein intake on growth, adipose tissue, and the insulin-like growth factor system in piglets. Pediatr Res 65, 45-50.

15. Association Française de Normalisation (AFNOR) (1997) Dosage de l'azote, méthode par combustion (DUMAS). Procédure ID: NF V 18-120 (Determination of nitrogen, combustion method (DUMAS). Procedure ID: NF V 18-120). In Aliments des animaux (Animal Feeds) [AFNOR, editor]. Paris: ANFOR éditions

16. Jeanson S, Dupont D, Grattard N, et al. (1999) Characterization of the heat treatment undergone by milk using two inhibition ELISAs for quantification of native and heat denatured $\alpha$-lactalbumin. J Agric Food Chem 47, 2249-2254.

17. Johansson A, Lugand D, Rolet-Repecaud O, et al. (2009) Epitope characterization of a supramolecular protein assembly with a collection of monoclonal antibodies: the case of casein micelle. Mol Immunol 46, 1058-1066.

18. Caussin F, Famelart MH, Maubois JL, et al. (2003) Mineral modulation of thermal aggregation and gelation of whey proteins: from $\beta$-lactoglobulin model system to whey protein isolate. Lait $\mathbf{8 3}, 353-364$.

19. Leonil J, Molle D, Fauquant J, et al. (1997) Characterization by ionization mass spectrometry of lactosyl $\beta$-lactoglobulin conjugates formed during heat treatment of milk and whey and identification of one lactose-binding site. J Dairy Sci 80, 2270-2281.

20. Senocq D, Dupont D, Rolet-Repecaud O, et al. (2001) Antipeptide antibodies recognizing plasmin sensitive sites in bovine $\beta$-casein sequence. J Agric Food Chem 49, 1571-1577.

21. Lindberg T, Engberg S, Jakobsson I, et al. (1997) Digestion of proteins in human milk, human milk fortifier, and preterm formula in infant rhesus monkeys. $J$ Pediatr Gastroenterol Nutr 24, 537-543.

22. Dupont D, Mandalari G, Mollé D, et al. (2009) Comparative resistance of food proteins to adult and infant in vitro digestion models. Mol Nutr Food Res 53, 767-780.

23. Inglingstad RA, Devold TG, Eriksen EK, et al. (2010) Comparison of the digestion of caseins and whey proteins in equine, bovine, caprine and human milks by human gastrointestinal enzymes. Dairy Sci Technol 90, 549-563.

24. Eriksen EK, Holm H, Jensen E, et al. (2010) Different digestion of caprine whey proteins by human and porcine gastrointestinal enzymes. Br J Nutr 104, 374-381.

25. Moreno FJ, Mackie AR \& Mills ENC (2005) Phospholipid interactions protect the milk allergen $\alpha$-lactalbumin from proteolysis during in vitro digestion. J Agric Food Chem 53, $9810-9816$

26. Mandalari G, Mackie AM, Rigby NM, et al. (2009) Physiological phosphatidylcholine protects bovine $\beta$-lactoglobulin from simulated gastrointestinal proteolysis. Mol Nutr Food Res 53, 131-139.

27. Moughan PJ, Cranwell PD \& Smith WC (1991) An evaluation with piglets of bovine milk, hydrolyzed bovine milk, and isolated soybean proteins included in infant milk formulas. II. Stomach emptying rate and the postprandial change in gastric $\mathrm{pH}$ and milk clotting enzyme activity. $J$ Pediatr Gastroenterol Nutr 12, 253-259.

28. Wilson RH \& Leibholz J (1981) Digestion in the pig between 7 and $35 \mathrm{~d}$ of age. 2. The digestion of dry matter and the $\mathrm{pH}$ of digesta in pigs given milk and soya-bean proteins. $\mathrm{BrJ}$ Nutr 45, 321-336.

29. Picariello G, Ferranti P, Fierro O, et al. (2010) Peptides surviving the simulated gastrointestinal digestion of milk proteins: biological and toxicological implications. $J$ Chromatogr B Analyt Technol Biomed Life Sci 878, 295-308.

30. Abubakar A (1998) Structural analysis of new antihypertensive peptides derived from cheese whey protein by proteinase K digestion. J Dairy Sci 81, 3131-3138.

31. Elitsur Y \& Luk GD (1991) $\beta$-Casomorphin (BCM) and human colonic lamina propria lymphocyte proliferation. Clin Exp Immunol 85, 493-497.

32. Kayser H (1996) Stimulation of human peripheral blood lymphocytes by bioactive peptides derived from bovine milk proteins. FEBS Lett 383, 18-20.

33. Saint-Sauveur D, Gauthier SF, Boutin Y, et al. (2008) Immunomodulating properties of a whey protein isolate, its enzymatic digest and peptide fractions. Int Dairy $J \mathbf{1 8}$, $260-270$.

34. Jacquot A, Gauthier SF, Drouin R, et al. (2010) Proliferative effects of synthetic peptides from $\beta$-lactoglobulin and $\alpha$-lactalbumin on murine splenocytes. Int Dairy $J \mathbf{2 0}$, $514-521$. 